\title{
Protected area surface extension in Madagascar: Do endemism and threatened species remain useful criteria for site selection?
}

Jeanneney Rabearivony', Russell Thorstrom", LilyArison Rene de Roland', Marius Rakotondratsima', Tolojanahary R. A. Andriamalala', The Seing Sam', Gilbert Razafimanjato', Daniel Rakotondravony", Achille P. Raselimanana ${ }^{\mathrm{III}, \mathrm{V}}$ and Michel Rakotoson'

\begin{abstract}
The 'hotspot approach' considers that endemism and threatened species are key factors in protected area designation. Three wetland and forest sites have been proposed to be included into Madagascar's system of protected areas (SAPM - Système des Aires Protégées de Madagascar). These sites are Manambolomaty $(14,701$ ha) and Mandrozo $(15,145$ ha) in the west and Bemanevika $(37,041$ ha) in the north. Biodiversity inventories of these three sites recorded 243 endemic species comprised of 44 reptiles, 54 amphibians, 104 birds, 23 small mammals, 17 lemurs and one fish. Of these 243 species, 30 are threatened taxa comprising two Critically Endangered (CR), 11 Endangered (EN) and 17 Vulnerable (VU) species. The long term ecological viability of these sites has been shown by population stability of the two Critically Endangered flagship species, the Madagascar fish eagle (Haliaeetus vociferoides) in Manambolomaty and Mandrozo and the recently rediscovered Madagascar pochard (Aythya innotata) in Bemanevika. Other threatened species and high biological diversity also justifies their inclusion into Madagascar's SAPM.
\end{abstract}

\section{RÉSUMÉ}

L'endémisme et les espèces menacées constituent les éléments clef pour la création des aires protégées. Trois zones humides de Madagascar ainsi que leurs forêts avoisinantes sont proposées pour la protection sous le nouveau système des aires protégées malgaches connu sous le sigle SAPM (Système d'Aires Protégées de Madagascar) : Manambolomaty (14.701 ha) et Mandrozo (15.145 ha) à I'Ouest et Bemanevika (37.041 ha) dans le Nord. Les inventaires biologiques entrepris dans ces trois sites ont montré que 243 espèces y sont endémiques, avec 44 reptiles, 54 amphibiens, 104 oiseaux, 23 petits mammifères, 17 lémuriens et un poisson. Parmi ces 243 espèces, 30 sont menacées d'extinction avec deux qui sont en danger critique d'extinction (CR), 11 en danger (EN) et 17 vulnérables (VU). La survie écologique à long terme de ces sites a été avérée avec la découverte de la stabilité des populations des deux espèces indicatrices en danger critique d'extinction que sont le Pygargue de Madagascar (Haliaeetus vociferoides) à Manambolomaty et

\author{
Correspondence: \\ Jeanneney Rabearivony \\ The Peregrine Fund, BP 4113 \\ Antananarivo 101, Madagascar \\ E-mail: jeanneney66@yahoo.fr
}

Mandrozo et une espèce récemment redécouverte, le Fuligule de Madagascar (Aythya innotata) à Bemanevika. La stabilité de plusieurs autres espèces menacées ainsi que la diversité biologique de ces sites justifient leur inclusion dans le SAPM. Les sept associations locales, deux à Manambolomaty, deux à Bemanevika et trois à Mandrozo, ont supporté le programme de suivi de ces sites ainsi que de ces espèces indicatrices en montrant ainsi leur engagement dans le processus de création des aires protégées. Le Peregrine Fund a travaillé dans ces sites en vue de mettre en synergie ses objectifs de conservation avec le développement socio-économique local.

KEYWORDS: SAPM, flagship species, Bemanevika, Mandrozo, Manambolomaty.

MOTS CLEFS : SAPM, espèces indicatrices, Bemanevika, Mandrozo, Manambolomaty.

\section{INTRODUCTION}

Madagascar's human population is estimated at 19 million, with more than $70 \%$ living in rural areas where they are entirely dependent on local natural resources for their livelihood, which has a great impact on biodiversity (Primack 2002, Brown 2007). Madagascar is one of eight important global biodiversity hotspots owing to its unique biota and the high degree of threat to its natural habitats (McNeely et al. 1990, Myers et al. 2000, Ganzhorn et al. 2001, Mittermeier et al. 2005). Unsustainable use of natural resources through slash-and-burn agriculture, cutting trees for fuel, clearing land for zebu grazing, hunting and fishing are considered the main reasons for loss of biodiversity and degradation of natural habitats in Madagascar (Messerli 2000, Primack 2002, Benstead et al. 2003, Mittermeier et al. 2005).

Since the 1980's, national and international efforts to preserve Madagascar's biodiversity have been significant (Mittermeier et al. 2005). Currently, under the Madagascar National Parks management (MNP formerly known as ANGAP = Association Nationale pour la Gestion des Aires Protégées), there are over 50 protected areas in Madagascar divided into Strict Nature Reserves (IUCN category I), National Parks (IUCN

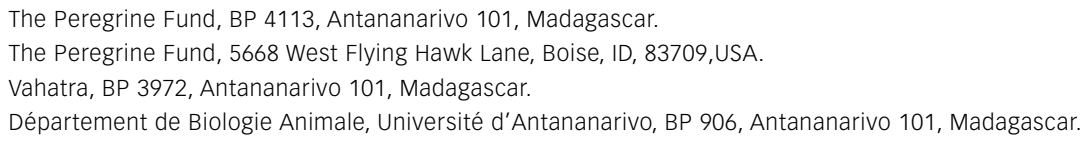




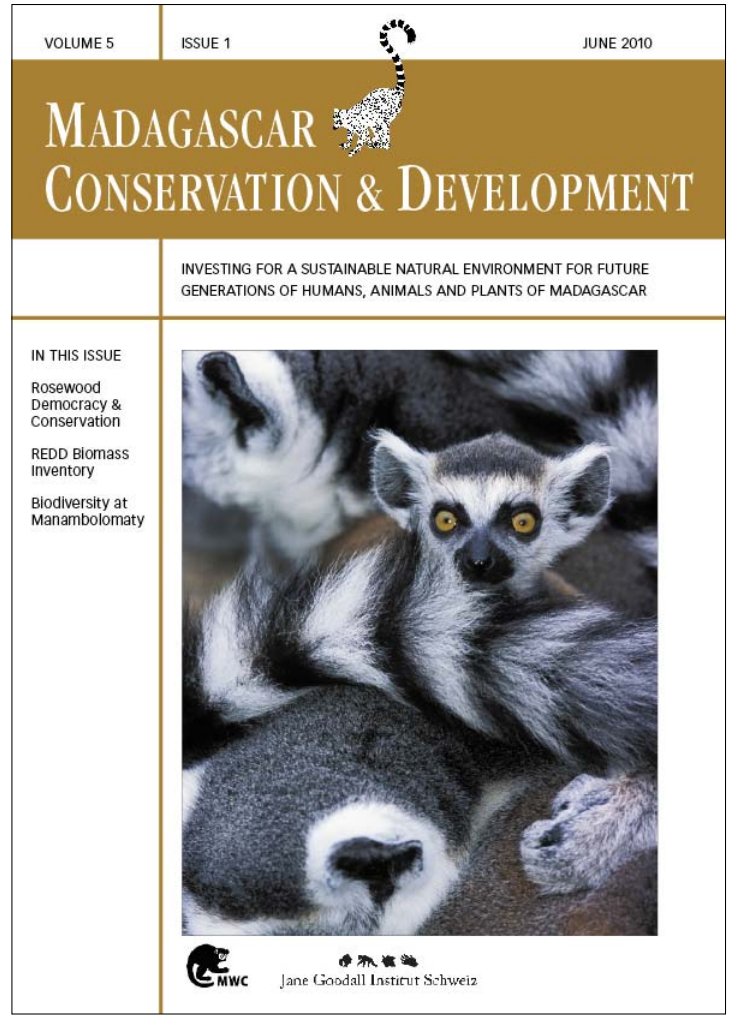

Madagascar Conservation \& Development is the journal of Madagascar Wildlife Conservation (MWC) and the Jane Goodall Institute (JGI Switzerland). It is produced under the responsibility of these institutions. The views expressed in contributions to MCD are solely those of the authors and not those of the journal editors or the publishers.

All the Issues and articles are freely available at http://www.mwc-info.net/en/services/journal.htm

\section{Contact Journal MCD}

info@journalmcd.net for general inquiries MCD funding@journalmcd.net for supporting the journal

Journal Madagascar Conservation \& Development Institute and Museum of Anthropology University of Zurich

Winterthurerstrasse 190

$\mathrm{CH}-8057$ Zurich, Switzerland

contact@mwc-info.net for general inquiries

Postfach 2701

CH-8021 Zürich, Switzerland

Logement 11, Cité Andohaniato

Antananarivo 101, Madagascar

info@janegoodall.ch for general inquiries JGI

\section{$2 \pi$ Jane Goodall Institut Schweiz}

Jane Goodall Institute Schweiz

Postfach 2807

8033 Zürich

switzerland 
category II) and Special Reserves (IUCN category IV) (Nicoll 2003, Mittermeier et al. 2005). MNP's primary objective is to have representation of Madagascar's various ecosystems and maintain the island's unique biodiversity (Nicoll 2003). The current protected area network covers some 1.7 million hectares or about $3 \%$ of the country (Mittermeier et al. 2005). However, recent gap analysis reveals, as for many protected areas in the world (Oldfield et al. 2004, Rodrigues et al. 2004), that the coverage of Madagascar's unique biodiversity by this network is far from adequate and requires a significant increase in protected area coverage (Mittermeier et al. 2005). There is a high risk of extinction of several newly described, endemic and threatened species outside of Madagascar's present network of protected areas (Andreone et al. 2001, Raxworthy and Nussbaum 2006, Rene de Roland et al. 2007, Sparks and Stiassny 2010). In 2003, the fifth World's Park Congress was held in Durban, South Africa. During the meeting, Madagascar's president recognized the value of protecting the country's unique natural heritage and stated his commitment to a national conservation plan that would triple the amount of protected area coverage (Mittermeier et al. 2005).

Cabeza and Moilanen (2001) stated that current strategies for designing a reserve are to maximize the number of species conserved within a minimum loss of habitat and land. This concept may lead sometimes to the issue of under representation of keystone species, those which are threatened and in need of strict protection (Kati et al. 2004, Oldfield et al. 2004), but it is clear that protection in situ remains the greatest hope for global conservation of biodiversity (Pressey 1996, Margules et al. 2002, Chape et al. 2005). This paper aims to present the importance of the three newly proposed Malagasy protected sites based on inventories of species, comparing the sites in terms of endemism and threatened taxa and monitoring of flagship species to show these sites are ecologically stable and justifiable for their inclusion into Madagascar's network of protected areas.

\section{STUDY AREA AND METHODS}

THREE PROPOSED SITES. The Malagasy government is presently working to add three more IUCN categories to Madagascar's newly protected areas system known as SAPM (Système des Aires protégées de Madagascar). These categories are Natural Monument (IUCN category III), Protected Landscape / Seascape (IUCN category V) and Reserve of Natural Resources (IUCN category $\mathrm{VI}$ ). For this purpose, we have proposed three new potential protected sites, Manambolomaty, Mandrozo and Bemanevika, into Madagascar's protected area network in Madagascar's commitment in conserving its unique biodiversity and natural heritage (see Figure 1). Manambolomaty is located in central western Madagascar, in the communes of Masoarivo and Trangahy, District of Antsalova, Region of Melaky (E44 ${ }^{\circ} 26^{\prime}, \mathrm{S} 19^{\circ} 01^{\prime}$ ) at seven meters of elevation. The Manambolomaty site is composed of four major lakes and part of the Tsimembo dry deciduous forest. On average, the lakes are 3-5 $\mathrm{m}$ deep with a maximum depth of five meters recorded at the end of the rainy season. In 1998, Manambolomaty was the first RAMSAR site in Madagascar. This site includes Soamalipo and Befotaka Lakes in the Masoarivo Commune and Ankerika Lake in the Trangahy Commune, for a total area of 14,701 ha of wetland and dry deciduous forest. The Manambolomaty Lakes complex is

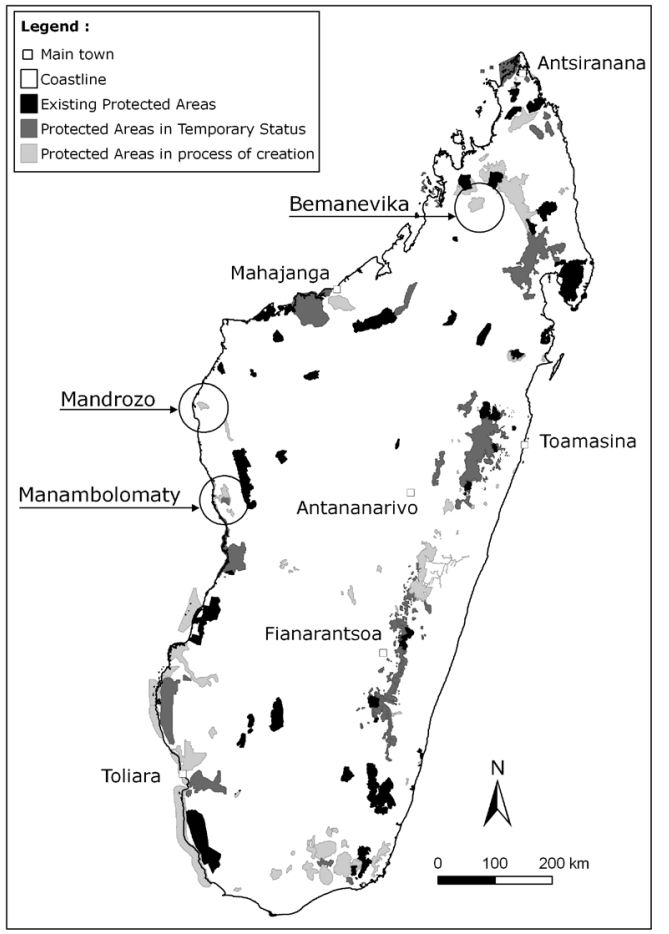

FIGURE 1. Map of the proposed SAPM sites of Manambolomaty, Mandrozo, and Bemanevika in Madagascar.

of natural origin and fed by the Manambolomaty River during the rainy season. The climate is characterized by a dry warm season extending from April to October and a hot rainy season from November to March. The annual rainfall varies from 499-1,193 $\mathrm{mm}$ (see Table 1) and the temperature ranges from $15-37^{\circ} \mathrm{C}$ (Razafimanjato et al. 2007). The dominant trees within the Tsimembo forest are Dalbergia sp. (Fabaceae), Delonix sp. (Fabaceae) and Cordyla madagascariensis (Fabaceae), which are approximately $12 \mathrm{~m}$ in height with a few emergent trees reaching up to $20 \mathrm{~m}$.

Mandrozo is a wetland site located within the three communes Veromanga, Andranovao and Tambohorano, District of Maintirano, Melaky Region, western Madagascar (E44 $05^{\prime}$, $\left.\mathrm{S} 17^{\circ} 32^{\prime}\right)$, and is approximately $280 \mathrm{~km}$ north of the Manambolomaty site. Mandrozo Lake has a surface area of 1,800 ha, and like many other lakes in western Madagascar it is fairly shallow with an average depth of 2-3 m (reaching up to over five meters during the rainy season). Rainfall data are lacking for this site, but due to similar seasonal variations, should be similar to the Manambolomaty site. It encompasses 15,145 ha, including Mandrozo Lake and the surrounding dry fragmented deciduous forest interspersed with palm forests and grasslands, and the elevation ranges from 7-60 m. The forest habitat is composed mainly of Millettia richardiana (Fabaceae), Trilepisium madagascariense (Moraceae) and Drypetes perrieri (Euphorbiaceae), which reach 6-10 $\mathrm{m}$ in height. The

TABLE 1. Annual rainfall at Manambolomaty Lakes Complex in western Madagascar from 2002, 2003, 2005-2007.

\begin{tabular}{|l|l|}
\hline Year & Rainfall $[\mathrm{mm}]$ \\
\hline 2002 & 499 \\
\hline 2003 & 1106 \\
\hline 2005 & 1006 \\
\hline 2006 & 1082 \\
\hline 2007 & 1193 \\
\hline
\end{tabular}


endemism rate for plants in Mandrozo is approximately $76 \%$ (The Peregrine Fund 2008a).

Bemanevika is located within two communes AntanagnivoHaut and Beandrarezona, District of Bealanana, Sofia Region, northwestern Madagascar (E48 $32^{\prime}, \mathrm{S}_{1} 4^{\circ} 22^{\prime}$ ), and covers an area of 37,041 ha. The topography is variable and comprises a mixture of valleys and mountains ranging from 700-1,800 $\mathrm{m}$ in elevation. The habitat types are heterogeneous and are composed mainly of five permanent lakes (Andriakanala, Maramarantsalegy, Matsaborimena, Matsaborimaitso and Matsaborimisivoay) with a total surface area of 150 ha, large patches of fragmented rainforest, several marshes, and expansive grasslands. The lakes are volcanic in origin with Matsaborimena the shallowest and Andriakanala the deepest, with maximum depths of two meters and $83 \mathrm{~m}$, respectively. The climate is tropical and humid, with annual precipitation ranging from 1,600-2,700 mm (Donque 1975). The rainy and dry seasons are the same as for the two previous sites, however, the temperature ranges from 10-30 ${ }^{\circ} \mathrm{C}$, and can dip below $10^{\circ} \mathrm{C}$ during the coldest period in July. The mature primary rainforest has a canopy ranging from 12-20 m, and is composed mostly of the following trees: Malleastrum rakotozafyi (Meliaceae), Weinmannia rutenbergii (Cunoniaceae), Plagioscyphus jumellei (Sapindaceae), Syzygium emirnense (Myrtaceae), Macphersonia gracilis (Sapindaceae), Filicium longifolium (Sapindaceae), Calophyllum milvum (Clusiaceae) and Tambourissa sp. (Monimiaceae).

DATA COLLECTION. Rapid Biological Assessment: In Bemanevika (December 2007 to January 2008) and Mandrozo (March to April 2008) rapid biological inventories of reptiles, amphibians, and birds were completed, but we were unable to inventory small mammals and lemurs at the Mandrozo site and fishes in Mandrozo and Bemanevika due to time and financial constraints. For ecological heterogeneity, these faunal groups we surveyed have been used for small-scale reserve designation (e.g., Kati et al. 2004). Four specific sites (Matsaborimena-Matsaborimaitso, Andriakanala, Morapitsaka and Matsaborimisivoay) were surveyed at Bemanevika and two (Analalava and Antsakoamalinika) at Mandrozo. Several types of inventory methods were used in order to assess the biodiversity of the proposed sites. Direct diurnal and nocturnal observations were made for all inventoried faunal groups.

For herpetofaunal surveys, refuge examination and pitfall traps were used. Refuge examination required researchers to search under leaf litter and rocks among dead wood, leaf axils of Pandanus palms, and on tree trunks during the day and night to record species (Raxworthy 1988, D'Cruze et al. 2007, 2008). Pitfall traps consisted of buckets (15 liters in volume) with handles removed dug into the ground and placed at $10 \mathrm{~m}$ intervals along a drift fence $100 \mathrm{~m}$ in length. The buckets were drilled with small holes in the bottom to allow water to drain (for more information on pitfall protocol, see Raxworthy 1988, Rakotomalala and Raselimanana 2003). At each specific site, traps were checked twice a day at 0600h and 1600 h during six consecutive trap days. No voucher specimen was taken from Mandrozo. Specimens from Bemanevika (research permit $\mathrm{N}^{\circ}$ 0295/07/MINENV.EF/SG/DGEF/DPSAP/SSE) were stored in $70 \%$ ethanol solution and housed in the laboratory of Animal Biology Department at the University of Antananarivo (Appendix 1).

Forest birds were directly counted using the Mackinnon and Phillips (1993) species-list approach. Researchers walked slowly (about 1-1.5 km per hour) along pre-existing trails and recorded bird species encountered or heard. To maximize species encountered, observations were conducted from 0430-0830h when birds were most active and vocal (Scott et al. 1981). Waterbirds were surveyed from observation points along lakeshores following the 'Look and See Method (opportunistic sighting)' by Bibby et al. (1998) using binoculars and spotting scopes. This direct observation technique (Perennou 1991) has been used by several researchers in western Madagascar for waterbird surveys and monitoring (e.g., Razafimanjato et al. 2007).

For mammal surveys, pitfall traps were used for small terrestrial mammals (Stephenson 1993, Soarimalala and Goodman 2003). Sherman live traps were also used to capture small mammals, and traps were baited with peanut butter and the distance between two consecutive traps varied according to the habitat. To maximize small mammal inventories traps were set on the ground, on decomposing trees, under tree roots, on tree trunks, dead leaves or leaf litter and along the river and / or lake shore. Pitfall and Sherman traps were checked twice a day at $0600 \mathrm{~h}$ and $1600 \mathrm{~h}$.

Literature review consists of compiling the available biological field data and is often used to support the biodiversity conservation strategies (Carpenter and Robson 2005). For faunal groups not inventoried during this study at Manambolomaty, species lists for lemurs, fishes and waterbirds were taken from Razanantsoa (2000), Rasamoelina (2000), and Razafimanjato et al. (2007), respectively.

Threatened Species and the International Union for Conservation of Nature (IUCN) Redlist: Information from the literature was used to determine species endemism in Madagascar (e.g., Reinthal and Stiassny 1991, Goodman et al. 2003, Hawkins and Goodman 2003, Raselimanana and Vences 2003, Sparks and Stiassny 2003, 2008). Each species was checked for its current population status from the IUCN 2008 Redlist to determine if it is Critically Endangered (CR), Endangered (EN), Vulnerable (VU), Near Threatened (NT), Least Concern (LC) or poorly known Data Deficient (DD). For conservation priority purpose, emphasis was given to those species listed in the three highest IUCN threat categories: CR, EN and VU (Raxworthy and Nussbaum 2000, Andreone et al. 2005a), although all IUCN categories were considered.

Flagship species monitoring: For long-term management objectives, two avian species sensitive to environmental change, the critically endangered Madagascar fish eagle (Haliaeetus vociferoides) (Watson et al. 1996, 2007, Watson and Rabarisoa 2000) and Madagascar pochard (Aythya innotata) (Rene de Roland et al. 2007) were monitored and used as indicator species to assess the environmental health of each site. In Manambolomaty and Mandrozo, Madagascar fish eagles were monitored following the survey methods described by Rabarisoa et al. (1997) and Watson et al. (2007). Each occupied nest was visited three times during the breeding season: Egg laying, nestling and dispersal periods to determine productivity (for more details see Rabarisoa et al. 1997 and Watson et al. 2007). In Bemanevika, for the critically endangered Madagascar pochard, surveys were conducted monthly at four of the five lakes by four teams composed of two persons per team. Each team counted the number of pochards observed every 10 minutes from 0600-1800h. Currently, the Bemanevika area is the only known and maybe the only 
viable site for this critically endangered duck in Madagascar (Rene de Roland et al. 2007).

\section{RESULTS}

ENDEMISM AND THREATENED SPECIES STATUS. Of the 16 species of fishes recorded in Manambolomaty, only one is endemic to Madagascar, Arius madagascariensis (Table 2, supplementary Material).

For amphibians, the Bemanevika site hosts 48 species, whereas 11 species were recorded at the drier Mandrozo site. In total, 58 species of amphibians were found at both sites of which 54 are endemic. Only one species, the Mascarene ridged frog Ptychadena mascareniensis, was found at both sites. The Bemanevika site had one endangered and four vulnerable species: Scaphiophryne boribory (EN), Boophis blommersae (VU), Gephyromantis striatus (VU), Mantella pulchra (VU) and Spinomantis massi (VU). None of the Mandrozo amphibian species are on IUCN's threatened species list, although the Western white-lipped treefrog Boophis occidentalis is considered Near-Threatened (NT).
A total of 57 reptile species were recorded in the Bemanevika and Mandrozo sites. Eighteen were found strictly in Bemanevika whereas there were 36 species in Mandrozo and three species were shared by both sites: Malagasy giant hognose snake Leioheterodon madagascariensis, Stripeneck skink Madascincus intermedius and Madagascar girdled lizard Zonosaurus madagascariensis. The Bemanevika site is richer in chameleon species ( $n=5$ species) than Mandrozo site ( $n=2$ species) whereas for other squamates, species richness was higher in Mandrozo than in Bemanevika (Supplementary Material). Combining both sites, a total of 44 endemic species was recorded, and according to the IUCN (2008) two are vulnerable, the Madagascar ground boa (Acrantophis madagascariensis) and Madagascar tree boa (Sanzinia madagascariensis), and one is endangered, the Madagascar big-headed turtle (Erymnochelys madagascariensis). None of the squamates and testudines found at the Bemanevika site are listed in the IUCN (2008) as threatened.

All avian species recorded at Manambolomaty were waterbirds. A comparison for forest bird species is only meaningful

TABLE 2. List of Endangered (EN) and Critically Endangered (CR) species recorded at the three SAPM sites and total number of taxa with endemism. For detailed list of taxa see Supplementary Material.

\begin{tabular}{|c|c|c|c|c|c|}
\hline & Bemanevika & Mandrozo & Manambolomaty & Endemic species & Status IUCN 2008 \\
\hline \multicolumn{6}{|l|}{ Fishes } \\
\hline Total & & & 16 & 1 & 4 \\
\hline \multicolumn{6}{|l|}{ Amphibians } \\
\hline Scaphiophryne boribory & * & & & * & EN \\
\hline Total & 48 & 11 & & 54 & 36 \\
\hline \multicolumn{6}{|l|}{ Reptiles } \\
\hline \multicolumn{6}{|l|}{ Pelomedusidae } \\
\hline Erymnochelys madagascariensis & & * & & * & EN \\
\hline Total & 18 & 36 & & 44 & 4 \\
\hline \multicolumn{6}{|l|}{ Birds } \\
\hline \multicolumn{6}{|l|}{ Ardeidae } \\
\hline Ardeola idae & * & * & & * & EN \\
\hline Ardea humbloti & & * & * & * & EN \\
\hline Threskiornis bernieri & & * & * & * & EN \\
\hline \multicolumn{6}{|l|}{ Anatidae } \\
\hline Anas melleri & * & & & * & EN \\
\hline Anas bernieri & & & * & * & EN \\
\hline \multicolumn{6}{|l|}{ Accipitridae } \\
\hline Eutriorchis astur & * & & & * & EN \\
\hline Haliaeetus vociferoides & & * & * & * & $\mathrm{CR}$ \\
\hline \multicolumn{6}{|l|}{ Rallidae } \\
\hline Amaurornis olivieri & & * & & * & $\mathrm{CR}$ \\
\hline \multicolumn{6}{|l|}{ Tytonidae } \\
\hline Tyto soumagnei & * & & & * & EN \\
\hline Total & 106 & 91 & 47 & 104 & 160 \\
\hline \multicolumn{6}{|l|}{ Micromammals } \\
\hline \multicolumn{6}{|l|}{ Muridae - Nesomyinae } \\
\hline Brachytarsomys villosa & * & & & * & EN \\
\hline Total & 25 & & & 23 & 22 \\
\hline \multicolumn{6}{|l|}{ Lemurs } \\
\hline \multicolumn{6}{|l|}{ Indridae } \\
\hline Avahi occidentalis & & & * & * & EN \\
\hline Total & 8 & & 10 & 17 & 13 \\
\hline
\end{tabular}


between Mandrozo and Bemanevika. Altogether, 161 avian species were recorded at the three sites, of which 106 were in Bemanevika, 91 in Mandrozo and 47 in Manambolomaty (waterbirds only) and 75 species were in common at least for two sites. In total, 104 endemic species were recorded at the three sites. At the Bemanevika site nine threatened species were recorded, of which five were waterbirds: Madagascar pochard Aythya innotata (CR), Meller's duck Anas melleri (EN), Madagascar pond heron Ardeola idae (EN), Madagascar rail Rallus madagascariensis (VU) and Madagascar little grebe Tachybaptus pelzelnii (VU), and four were forest birds: Madagascar serpent-eagle Eutriorchis astur (EN), Madagascar red owl Tyto soumagnei (VU), Madagascar harrier Circus macrosceles (VU) and Bernier's vanga Oriolia bernieri (VU). At Mandrozo, five threatened species were recorded: Madagascar fish eagle Haliaeetus vociferoides (CR), Sakalava rail Amaurornis olivieri (EN), Madagascar heron Ardea humbloti (EN), Madagascar pond heron Ardeola idae (EN) and Madagascar white ibis Threskiornis bernieri (EN). Manambolomaty has six threatened species: Madagascar fish eagle (CR), Madagascar teal Anas bernieri (EN), Madagascar heron (EN), Madagascar white ibis (EN), Madagascar plover Charadrius thoracicus (VU) and Madagascar little grebe (VU).

At Bemanevika, 25 small mammal species were recorded of which 23 are endemic, and one is endangered, the poorly known Hairy-tailed tree rat Brachytarsomys villosa (EN) (IUCN 2008). For lemurs at Manambolomaty, one species is endangered, the Western avahi Avahi occidentalis (EN) and two are vulnerable, Western lesser bamboo lemur Hapalemur occidentalis (VU) and Milne-Edward's sportive lemur Lepilemur edwardsi (VU). At Bemanevika only one vulnerable lemur species was recorded, the Western grey bamboo lemur (VU) (Mittermeier et al. 2006).

MONITORING OF FLAGSHIP SPECIES. The annual

populations for Madagascar pochards and Madagascar fish eagle have remained relatively stable since the beginning of community-based conservation activities (see Table 3). From 2007-2008, the Madagascar pochard's global population has been stable at 18-20 individuals, and is most likely near or at carrying capacity. Displacements from Matsaborimena Lake have been observed, and some individuals have been observed on two other lakes, Andriakanala and Matsaborimaitso. Movement to a small man-made pond in Bemanevika village has been observed too (J. Ramamonjisoa, pers. com.)

TABLE 3. Monitoring of the critically endangered Madagascar Fish Eagle (Haliaeetus vociferoides) at Mandrozo and Manambolomaty and the critically endangered Madagascar Pochard (Aythya innotata) at Bemanevika.

\begin{tabular}{llcccc}
\hline Site & Monitoring species & Year & Male & Female & Total \\
\hline Bemanevika & Aythya innotata & 2007 & - & - & 20 \\
& & 2008 & - & - & 18 \\
\hline Mandrozo & Haliaeetus vociferoides & 2006 & 6 & 6 & 12 \\
& & 2007 & 6 & 6 & 12 \\
& & 2008 & 5 & 5 & 10 \\
\hline Manambolomaty & Haliaeetus vociferoides & 2002 & 18 & 9 & 27 \\
& & 2003 & 18 & 9 & 27 \\
& & 2004 & 19 & 11 & 30 \\
& & 2005 & 18 & 11 & 29 \\
& 2006 & 20 & 12 & 32 \\
& 2007 & 20 & 11 & 31 \\
& & 2008 & 21 & 11 & 32 \\
\hline
\end{tabular}

In Mandrozo, from 2006 to 2008, the population of Madagascar fish eagles remained stable at 10-12 individuals. At the Manambolomaty site, population size of the Madagascar fish eagles varied from 27 to 32 individuals during a seven-year monitoring period (2002 to 2008). At Manambolomaty, about 70-80\% of Madagascar fish eagles' nests contain two males and one female, and in Mandrozo all pairs were one male and one female.

\section{DISCUSSION}

LINKING THREATENED TAXA WITH HABITAT VARIABILITY.

There is little chance to conserve biodiversity without saving the important habitats for fauna and flora. Failure to include sufficient habitat variation within conserved patches may lead to species extinction in unfavorable years (Kirby 1993). The importance of Madagascar's eastern rainforest in maintaining species diversity is well documented (Raxworthy 1988, Kremen et al. 1999) while western deciduous forests and transitional ecosystems are often overlooked in Madagascar's biodiversity conservation strategy (Ramanamanjato et al. 2002, Rakotomalala 2008, Raselimanana 2008). To fill this gap, the three current SAPM proposed sites will contain varied habitats and ecosystems that are under-represented in today's Madagascar protected area network: Wetlands, deciduous and transitional forests, lakes, and grasslands or wooded grasslands.

The three proposed sites (Manambolomaty, Mandrozo, and Bemanevika) contain at least two important habitats: freshwater lakes and forests. Inclusion of these three sites, which we have documented as being biologically diverse and rich, will help to conserve many threatened taxa and add to the protection of Madagascar's wetland ecosystem. The protection of the Manambolomaty and Mandrozo Lakes will continue to conserve important critical wetland habitat for Madagascar fish eagles within their current range, and about $20 \%$ of the global population based on surveys in 2005 (The Peregrine Fund unpubl. data). The three lakes at the Bemanevika site (Matsaborimena, Matsaborimaitso and Andriakanala) are home to the only known and last viable population of Madagascar pochards (Rene de Roland et al. 2007). Categorized by the IUCN (2008) as critically endangered (CR), these two water-dependant species are listed amongst the world's 189 most threatened birds (Birdlife International 2008). Not including these two critically endangered species, many other threatened waterbirds such as the Sakalava rail Amaurornis olivieri (EN), Madagascar teal Anas bernieri (EN), Meller's duck Anas melleri (EN), Malagasy heron Ardea humbloti (EN), Malagasy pond heron Ardeola idae (EN), Madagascar sacred ibis Threskiornis bernieri (EN), Madagascar plover Charadrius thoracicus (VU), Madagascar rail Rallus madagascariensis (VU), and Madagascar little grebe Tachybaptus pelzelnii (VU), plus the endangered Madagascar big-headed turtle Erymnochelys madagascariensis (EN), will benefit from the conservation of these protected wetlands.

The contribution of western and northern forest ecosystems to the conservation of endemic and threatened Malagasy taxa has been previously demonstrated for several species of reptiles (Raxworthy and Nussbaum 1995, 2006, Andreone et al. 2000, 2001), amphibians (Andreone et al. 2000), small mammals (Soarimalala and Goodman 2003) and birds (Seddon and Tobias 2007). Many of these taxa have localized or restricted distribu- 
tions in unprotected areas (e.g., Andreone et al. 2001, Raxworthy and Nussbaum 2006).

The primary forest cover has declined since 1962, especially in western Madagascar, and by 2000 the annual rate of deforestation has increased, to an estimated $0.93 \%$ per annum (Seddon et al. 2000, Tobias and Seddon 2002). Protecting the two western deciduous forests surrounding the Manambolomaty and Mandrozo Lakes, and the transitional forest in Bemanevika will be beneficial for conservation of Madagascar's natural heritage and biodiversity. The Bemanevika site has a large network of grasslands that are intermixed with marshes, an ecosystem important in protecting too. Fisher and Robertson (2002) highlighted the importance of upland and wooded grasslands in maintaining ant diversity. The critically endangered frog Mantella aurantiaca is known as a marsh-dependant species (Zimmermann and Hetz 1992, Zimmermann 1996, Bora et al. 2008). The Madagascar harrier Circus macrosceles (VU) also uses marshes for nesting, and it is highly dependent on grasslands and wooded grasslands for foraging habitat (Rene de Roland et al. 2004). Recent surveys throughout Madagascar in 2005 and 2006 recorded the greatest concentration of this vulnerable wetland dependent species at the Bemanevika site (Rene de Roland et al. 2009).

CONSERVATION VALUE OF THE THREE SITES FOR

ENDEMICAND THREATENED TAXA. Fishes: Although Stiassny and Raminosoa (1994) recorded only 42 species of freshwater fishes from Madagascar, recent survey work has lead to more than a tripling of this (Sparks and Stiassny 2008). Sparks and Stiassny (2003) listed 143 native (93 endemic) freshwater species, which was recently updated to 159 native freshwater species by sparks and Stiassny (2008). In Madagascar, three main threats for freshwater fish populations have been identified: Over-fishing, deforestation and introduced species (Reinthal and Stiassny 1991, Benstead et al. 2000, 2003). Sixteen species of fishes have been recorded at the Manambolomaty site, of which one is endemic to Madagascar (Arius madagascariensis). A. madagascariensis is widespread in the lower reaches of rivers, lakes and estuaries, and is common in western Madagascar (Ng and Sparks 2003a). Malagasy freshwater fish diversity is still very poorly known, and the conservation of threatened taxa is extremely difficult given current threats to aquatic systems (Sparks and Stiassny 2003). For conservation purpose, ichthyological surveys around Mandrozo and Bemanevika regions should be high conservation priorities in Madagascar. For instance, the basins immediately north and south of the Maevarano River Basin, where Bemanevika is situated, supports endemic clupeids, killifish, ariid catfish and cichlids (Loiselle and de Rham 2003a, Ng and Sparks 2003b, Sparks 2003). Moreover, drainages and lakes around Bemanevika may support many species of fishes originally described from the Sofia and Ankofia drainages whose long-term survival is extremely unlikely (Sparks 2003). Owing to the lack of information on fishes in the Bemanevika area, fish surveys are needed for the five permanent lakes (Andriakanala, Maramarantsalegy, Matsaborimena, Matsaborimaitso and Matsaborimisivoay) (J. Rabezandry, pers. com.). For Manambolomaty, Pachypanchax species - whose taxonomic status remains to be determined does occur in several drainages from Antsalova and Manambolo but is likely absent from the Manambolomaty Lakes (Loiselle and de Rham 2003b). The protection of local forests and the Manambolomaty wetlands will help to assure the integrity of this watershed where this species may occur. Furthermore, the inclusion of this site into Madagascar's protected area network will probably not only reduce the level of threat associated with deforestation, but might also help to overcome the frequent bias in protected area designation in Madagascar, which tends to ignore aquatic diversity (Sparks and Stiassny 2003). However, as protected area creation is a mid- or long-term process (taking at least 3-4 years to obtain definitive protection status), the monitoring of key environmental resources should start early to ensure long-term viability of these proposed sites.

Amphibians and Reptiles: The biodiversity richness of amphibians and reptiles is higher in Bemanevika than in Mandrozo (Table 2, and Supplementary Material). Ramanamanjato et al. (2002) have already highlighted the importance of a transitional forest in maintaining herpetofauna diversity and endemism. Of 48 amphibian taxa found in Bemanevika, five are threatened: One species is endangered, Scaphiophryne boribory (EN) and four are vulnerable Boophis blommersae (VU), Gephyromantis striatus (VU), Mantella pulchra (VU) and Spinomantis massi (VU). Overall, at both sites, $93 \%$ (54 out of 58) of recorded taxa are endemic (Supplementary Material). Madagascar, as a biodiversity hotspot country, is known for its high endemism of amphibians with 217 known species of which 215 are endemic (Stuart et al. 2004, Mittermeier et al. 2005). The high rate of deforestation and general habitat degradation are the most immediate threats to the amphibian species (Vallan 2002, 2003, Andreone et al. 2005a). It is therefore important to review the current conservation status for the most affected taxa (Andreone et al. 2005a).

Recent global amphibian assessment in Madagascar considered Scaphiophryne boribory as an endangered species and one of the taxa at risk of extinction because it has a restricted range where it is found only in a few protected areas (Andreone et al. 2005a, Glaw and Vences 2007). It is also collected for the international pet trade and the impact of this market is mostly unknown (Glaw and Vences 2007). The occurrence of S. boribory at Bemanevika extends its range into higher altitude forests, as it is known previously only from sites below $1,000 \mathrm{~m}$ (Andreone et al. 2005a). Its threatened status is thus worthy of special attention in defining new protected areas. The 'flagship approach' may be useful for the conservation of Mantella frogs and other amphibian species in Madagascar, but the major threats of Mantella frogs is the ongoing habitat destruction and exploitation for the international pet trade (Rabemananjara et al. 2005, Andreone et al. 2005ab). They are endemic, colourful and attractive and listed in CITES Appendix II (Glaw and Vences 2007). For example M. pulchra, a widely distributed species, is regularly seen in the international markets (Andreone et al. 2005a), but as with other traded amphibian species, studies of the effects of commercial collecting are lacking (Andreone et al. 2005a). The consideration of a Mantella site, as supported by Andreone et al. (2005a) may help to conserve the M. pulchra in Bemanevika, and other threatened amphibians such as Boophis blommersae (VU), Gephyromantis striatus (VU), or Spinomantis massi (VU).

of 57 reptiles species found in Bemanevika and Mandrozo, 44 species are endemic, two snake species are vulnerable (Acrantophis madagascariensis and Sanzinia madagascariensis) and one is endangered, the Madagascar big-headed 
turtle (Erymnochelys madagascariensis). This high endemism of reptiles supports the overall findings that about $91 \%$ of Malagasy reptiles (314 species out of 346) are endemic to the island (Raxworthy 2003a). A recent global survey of biodiversity hot spots found just two other regions, the Caribbean and Meso-America, with a greater reptile species endemism than Madagascar (Myers et al. 2000). Although widely distributed and tolerant of human-habitat modification (Raxworthy and Nussbaum 2000, Raxworthy 2003b), Madagascar's boas A. madagascariensis and S. madagascariensis remain vulnerable to extinction (Raxworthy 2003b, IUCN 2008). Despite national protection in Madagascar since the 1960s, the three Malagasy boas A. dumerili, A. madagascariensis and S. madagascariensis are collected commercially for skins and used primarily in the souvenir leather trade (Raxworthy 2003b). They have been listed on The Convention on International Trade in Endangered Species of Wild Fauna and Flora (CITES) Appendix I since 1977. Conservation of the Mandrozo site could provide these species a higher level of protection although current impact of commercial collection remains unknown (Raxworthy 2003b). Apparently, the absence of boas in Bemanevika is most likely a result of nearly all the forested and varying habitat being above their altitudinal range of 1,000 m (Raxworthy 2003b). The Madagascar big-headed turtle is a large species, with a carapace up to $50 \mathrm{~cm}$, and is found in the lowlands of western Madagascar between the Mangoky River in the south and the area of Boriziny in the north (Kuchling and Garcia 2003). The Mandrozo site is within its distribution, and it is also known from the Manambolomaty site (Rabearivony et al. 2008). Despite being protected, some individuals are harvested before reaching sexual maturity (Kuchling and Garcia 2003). Currently, the Madagascar big-headed turtle is in a serious noncyclical decline over its whole range (Kuchling and Garcia 2003). It is classified as endangered by IUCN status owing to an estimated population reduction of more than $50 \%$ over the past three generations (Kuchling and Garcia 2003). It is also a key indicator species of clean and open water (Kuchling and Garcia 2003). Its presence at the Mandrozo site indicates that this natural wetland continues to be an important area for preserving this rare freshwater turtle.

The high diversity of chameleon species in the northern region of Madagascar has been well documented (Raxworthy and Nussbaum 1995, 2006, Andreone et al. 2001). Of five chameleon species found in Bemanevika, two are recently described taxa, Calumma hafahafa and C. crypticum (Raxworthy and Nussbaum 2006). C. hafahafa is known to occur only in the Bemanevika area, which contributes to the importance of this site too (Raxworthy and Nussbaum 2006). Near the Bemanevika site at Ambolokopatrika, Andreone et al. (2001) found two local endemic chameleon species C. vatosoa and $C$. vencesi and, therefore, claimed the conservation of a long forest corridor between different reserves in the north is urgently needed. Faced with the negative impacts of climate change on Madagascar's biodiversity (Raxworthy et al. 2008), high altitudinal rainforests like Bemanevika could form the last refuge for many herpetofaunal species.

The comparison of Bemanevika and Mandrozo higher reptile diversity to other legally protected areas in Madagascar such as Anjanaharibe-Sud in northern Madagascar, Ampijoroa in northwestern and Tsingy de Bemaraha in midwestern, could also support the inclusion of these two wetland sites into Madagascar's protected area network. Also, Bemanevika with 18 species of reptiles is more diverse than Anjanaharibe-Sud with 13 species, as both are higher elevation sites in northern Madagascar (Rakotomalala and Raselimanana 2003). In western Madagascar, the total reptiles recorded at Ampijoroa (nine species) and Tsingy de Bemaraha (17 species) (Emanueli and Jesu 1995, Schimmenti and Jesu 1997, Mori et al. 2006) are less diverse than those recorded at Mandrozo (36 species) during this study. The discovery of the Neon day gecko Phelsuma klemmeri at Mandrozo extended its known distribution approximately $600 \mathrm{~km}$ farther south towards mid-western Madagascar, as it is previously known to occur only in the coastal area of Sambirano (Glaw and Vences 2007). About $20 \%$ of reptile taxa found in Mandrozo (seven of 36 species) are CITES Appendix II species (Brookesia brygooi, Furcifer lateralis, F. oustaleti, Uroplatus guentheri, Phelsuma madagascariensis, P. mutabilis, P. klemmeri) and, if commercial collecting takes place, this activity may affect the survivorship of these reptile populations. Moreover, most of Malagasy reptile species have not been evaluated (NE: Not Evaluated) on the IUCN Red List. This is one of the major issues in reptile conservation in Madagascar and, in the future, if all species are assessed, the importance of Bemanevika and Mandrozo for biodiversity conservation might likely increase.

Birds: Recently, the importance of Manambolomaty, Mandrozo, and Bemanevika sites in maintaining threatened avifauna diversity has been highlighted (Razafimanjato et al. 2007, Rene de Roland et al. 2007, BirdLife International 2008, Rabearivony et al. 2008, Rabenandrasana et al. 2009), and national protection of these sites may conserve at least 104 endemic forest birds and waterbirds of which 20 species are threatened (Table 2 and Supplementary Material). Of the 11 threatened taxa documented at the three sites seven are found only at Bemanevika (Madagascar pochard Aythya innotata (CR), Meller's duck Anas melleri (EN), Madagascar serpent-eagle Eutriorchis astur (EN), Madagascar red owl Tyto soumagnei (VU), Madagascar harrier Circus macrosceles (VU), Bernier's Vanga Oriolia bernieri (VU) and Madagascar rail Rallus madagascariensis (VU)), three at Manambolomaty (Madagascar fish eagle Haliaeetus vociferoides (CR), Madagascar teal Anas bernieri (EN) and Madagascar Plover Charadrius thoracicus (VU)) and two at Mandrozo (Madagascar fish eagle Haliaeetus vociferoides (CR) and Sakalava rail Amaurornis olivieri (EN)). All threatened waterbirds at these sites have declining populations attributed to human activities such as hunting, degradation of wetland habitat by conversion to rice paddies, and burning and collecting of wetland plants such as Phragmites and Cyperus species (Rene de Roland et al. 2007, BirdLife International 2008, Rabenandrasana et al. 2009). In addition, as a consequence of deforestation, wetlands have become shallower from siltation and have driven the loss of suitable habitat for most of the critical endangered waterbirds (BirdLife International 2008). Until recently, for instance, the Madagascar pochard was classified as a species 'possibly extinct' in the world (BirdLife International 2004, Butchart et al. 2006). The presence of the Sakalava rail at Mandrozo is noteworthy as it might be 'locally extinct' in some areas where it was previously recorded, e.g., at Lake Bemamba and Nosy Ambositra marsh (Rabenandrasana et al. 2009). Among the least known of the country's waterfowl, the 
Madagascar teal was rediscovered in 1969 when small numbers were found in Bemamba and Masama Lakes south of Antsalova (Salvan 1970, Andriamampianina 1976, Young et al. 2003). In 1973, 140 individuals were recorded at these lakes (Scott and Lubbock 1974) and, currently, its population is fragmented from Loky Bay in the north to Tsimanampetsotsa Lake in the south (Young et al. 2003). The only presences reported for this species have been at Lake Antsamaka, at the Manambolomaty RAMSAR site, and in the estuaries of the Betsiboka and Tsiribihina Rivers (Thorstrom and Rabarisoa 1995, Young et al. 2003). The inclusion of the three important host sites such as Bemanevika, Mandrozo and Manambolomaty into Madagascar's protected area network may help to slow down the declining population trend of these threatened waterbird species listed above.

The Madagascar serpent-eagle (EN) is a forest-dependent species that is known mainly from the primary eastern rain forests of Madagascar (Thorstrom et al. 2003, Thorstrom and Rene de Roland 2003ab). The Madagascar serpent-eagle was once regarded as one of the rarest birds of prey in the world owing to the loss of the primary forest cover (Collar et al. 1994), but due to the work of The Peregrine Fund it is now well known throughout many eastern rainforest blocks (Thorstrom and Rene de Roland 2003b). Also, the Madagascar serpent-eagle is a secretive species with a low productivity and this may also contribute to its rarity in Madagascar (Thorstrom and Rene de Roland 2003b). Another threatened raptor species, the Madagascar harrier (VU) is dependent on marsh, grassland and wooded grassland habitats for its survival (Thorstrom et al. 2003). It has an extremely broad distribution in Madagascar, but three major threats were recently identified to reducing its suitable habitat: Local consumption of eggs, nestlings and adults as food source for protein; burning of grasslands to stimulate fodder for cattle and land clearing; and the conversion of low-altitude marshes and wetlands into rice fields for human food production (Rene de Roland et al. 2004). However, apart from the raptor species mentioned, many other threatened forest birds may also benefit from the protection of these three sites. For example, the Bernier's vanga (VU) was reported to occur from sea level to

1,000 m (Langrand 1990, Thorstrom and Rene de Roland 2001), but was found in Bemanevika at 1,600 m (L.-A. Rene de Roland, pers. obs.). It has a limited distribution in eastern rainforests and appears to be relatively rare throughout its range in northern Madagascar (Langrand 1990, Evans et al. 1992, Thompson and Evans 1992).

Small mammals: At the Bemanevika site $92 \%$ (23 of 25 species) of the small mammals recorded are endemic (Supplementary Material). The only two introduced species confirmed at this site were those widely spread throughout Madagascar, the Black rat Rattus rattus and Asian house shrew Suncus murinus (Goodman et al. 2003). Historically, these two species were introduced by the earliest humans migrating to Madagascar's coastal areas (Duplantier and Duchemin 2003). In Bemanevika, we found the Hairy-tailed tree rat Brachytarsomys villosa (EN), which was elevated to species status 20 years ago (Carleton and Schmidt 1990). The Hairy-tailed tree rat $B$. villosa had never been found in the wild until a recent survey by Goodman et al. (2001) at Anjanaharibe-Sud special Reserve.

Lemurs: All of the 71 species and sub-species of lemurs are endemic to Madagascar (Mittermeieret al. 2006). A total of 17 taxa were recorded for the Bemanevika (8 species) and Manambolomaty (10 species) sites, with the Aye-aye (Daubentonia madagascariensis) being encountered on both. Although the Aye-aye has been found in many new localities and in many different parts of Madagascar, this nocturnal lemur does not appear to be abundant anywhere. Its numbers are believed to be declining with the loss of forest habitat (Sterling 1994, Mittermeier et al. 2006), and it is currently classified as Data Deficient according to IUCN (2008). Many records for this species are based only on interviews with local people or research guides (e.g., Randrianambinina et al. 2003, Olivieri et al. 2006, Randrianambinina and Rasoloharijaona 2006). In 2005, one individual was found in a fig tree Ficus sp. growing in the middle of a banana plantations along the Manambolomaty seasonal river (J. Rabearivony and L.-A. Rene de Roland, pers. obs.), and in 2006, another individual was observed on the forest edge of Soamalipo Lake (L.-A. Rene de Roland, pers. obs.). A live animal was captured at Bemanevika site in 2000 by a villager in Amberivery, about $15 \mathrm{~km}$ south of this site; scraping signs by this species were also observed on a dead tree in 2008 (Lhota et al. 2008, The Peregrine Fund 2008b). Except for the Aye-aye and Western avahi Avahi occidentalis, all of the lemur species recorded at the Manambolomaty site during biodiversity inventories had also been confirmed by Ausilio and Raveloarinoro (1998). Lemur taxonomy is still in the process of revision due to a surge in discoveries and additional information on distributions (Ganzhorn et al. 2006), which could add up to the lemur diversity at both the Manambolomaty western deciduous forest and the Bemanevika transitional rainforest sites (Supplementary Material). Four threatened species were recorded during these inventories: Western avahi Avahi occidentalis (EN), Grey bamboo lemur Hapalemur griseus (VU), Milne-Edward's sportive lemur Lepilemur edwardsi (VU) and Western grey bamboo lemur H. occidentalis (VU) most likely experiencing similar conservation threats. These threats are habitat loss or destruction through burning to create new pasture for livestock or for practicing hill rice cultivation, charcoal production and mining (Mittermeier et al. 2006). Repeated burning of forests can result in extirpation of some lemur species like the Coquerel's sifaka Propithecus coquereli at the Bora Special Reserve (Koenig and Zavasoa 2006). Throughout Madagascar, and in many villages, Grey bamboo lemurs $\mathrm{H}$. griseus (VU) are also frequently kept as pets. Furthermore, all four threatened species including many other threatened lemur taxa, are hunted unsustainably (Garcia and Goodman 2003, Patel et al. 2005, Mittermeier et al. 2006). Impacts of human activities might be much more severe to species with narrow geographical distributions such as Western avahi Avahi occidentalis (EN). Currently, only one legally protected area Ankarafantsika National Park, hosts a high density (estimated at 67 individuals $/ \mathrm{km}^{2}$ ) of this species (Ganzhorn 1988), and a protected area network extension under SAPM may help to protect this and other lemur species from local extinction too (Mittermeier et al. 2006).

LONG-TERM CONSERVATION OF THE SITES. Protection

of a flagship species is very important in conservation as it helps to protect many other threatened species, biodiversity and ecosystems (Landres et al. 1988, Favreau et al. 2006). This has previously been demonstrated in the Manambolomaty site by using the critically-endangered Madagascar fish eagle as a flagship species (Rabearivony et al. 2008). 
Thus, conservation efforts to protect the Madagascar fish eagle at Manambolomaty can benefit other threatened taxa like for examples the Western avahi Avahi occidentalis (EN), Grey bamboo lemur Hapalemur griseus (VU) and Milne-Edward's sportive lemur Lepilemur edwardsi (VU)), bats (e.g. Flying fox Pteropus rufus (VU), birds (e.g., Madagascar heron Ardea humbloti (EN), Madagascar sacred ibis Threskiornis bernieri (EN), Madagascar little grebe Tachybaptus pelzelnii (VU) and Madagascar plover Charadrius thoracicus (VU), and reptiles, e.g., Madagascar big-headed turtle Erymnochelys madagascariensis (EN). During the 8-years (2002-2009) of community-based wetlands and Madagascar fish eagle conservation in Manambolomaty, the population of Madagascar fish eagle has remained stable at 27-32 individuals (Table 3).

The two local Associations in Manambolomaty FIZAMI (Flkambanana Zanatany Andranobe MIray) and FIFAMA (FIkambanana FAmpandrosoana Mamokatra Ankerika) have demonstrated their ability to ensure the ecological viability of this site in managing their natural resources as a sustainable source of revenue (Rabearivony et al. 2008). Currently, we are duplicating the same community-based wetland conservation strategies around Mandrozo Lake, which have been achieved at the Manambolomaty site. Recent monitoring revealed 5-6 pairs of Madagascar fish eagle at this site (Table 3 ). With an increased commitment from local and regional authorities i.e. the Tompondrano (lake keeper) and stakeholders, the three local Associations FIVOMA (FIkambanana Vonjisoa MAndrozo), FIMITOVE (FIkambanana Mlaro Tontolo iainana VEromanga) and ZAMAMI (ZAnatany MAndrozo MItambatra) in charge of the wetlands management are currently operating well. Thus, like in the Manambolomaty site, many threatened taxa will also receive the benefit from the protection of the critically endangered Madagascar fish eagle (see Supplementary Material for exhaustive list).

In Bemanevika, the Madagascar pochard occupies the same lakes as the Meller's duck Anas melleri (EN) and Red-billed teal Anas erythrorhyncha (LC). Currently, the minimum size of a viable population is unknown for the Madagascar pochard with $100 \%$ of the global population being at this site only. The survival of the remaining 18-20 individuals in Bemanevika is of great concern, as it is one of the most endangered bird species in the world (BirdLife International 2004, Butchart et al. 2006). Presently, a captive breeding program is in progress to conserve this critically-endangered species. However, because local people are very sensitive of foreigners (including all nongovernmental organisations working on bird conservation), they believe the foreigners may steal, sell and export this rare duck, and this local attitude has lead to a conservation and captive breeding program 'in situ' to maintain local social stability. Since conservation should focus mainly on the management of all human-induced pressures and activities (e.g., hunting, transformation of lakes to rice fields), the local stakeholders in Bemanevika are represented by two associations FBM (Fikambanana Bemanevika Miraihina) and FIMAKA (FIkambanana Miaro ny Ala Ketsany Amberivery) and they are supporting the Madagascar pochard conservation program and have shown their active involvement in the protected area creation process of this site.

\section{CONCLUSION}

The three proposed sites Manambolomaty, Mandrozo, and Bemanevika, support several endemic and highly threatened vertebrate taxa of fish, herpetofauna, birds, small mammals and primates. The population stability of the two flagship species, the Madagascar fish eagle in Manambolomaty and Mandrozo and the Madagascar pochard in Bemanevika, indicates that these three sites are ecologically stable. The hotspot approach based on the endemism rate and IUCN species Redlist supports the justification of protecting these three important wetland sites. However, it is emphasized that biodiversity protection works better if it is coupled with local resource management and socio-economic consideration (see Rabearivony et al. 2008).

\section{ACKNOWLEDGEMENTS}

Biodiversity inventories and socio-economic assessments in Bemanevika were financially supported by Conservation International $(\mathrm{Cl})$ and in Mandrozo by The Peregrine Fund, Liz Claiborne and Art Ortenberg Foundation, and Little Foundation. Research permits for these three sites were issued by the Ministère de l'Environnement et des Forêts. Field work was completed by The Peregrine Fund biologists and technicians from Antsalova and Masoala, and also assisted by consultants: Bertrand Razafimahatratra, Manajary A. Andriamazava, Nantenaina H. Randrianantsoa, Angelo T. Josso, Malalatiana Razafindrakoto, Ninah Tahinasoa, Ravalison, Maminiaina Andriamahenitsoa and Robert N. Tilahy. Local and regional Forestry Service personnel as well as the local communities at Manambolomaty, Mandrozo and Bemanevika are also acknowledged for their invaluable support, time and expertise. We are grateful to four anonymous reviewers for their many helpful comments on improving the early draft of this manuscript.

\section{REFERENCES}

Andreone, F., Randrianirina, J. E., Jenkins, P. D. and Aprea, G. 2000 Species diversity of Amphibia, Reptilia and Lipotyphla (Mammalia) at Ambolokopatrika, a rainforest between Anjanaharibe-Sud and Marojejy massifs, NE Madagascar. Biodiversity and Conservation 9, 12: 1587-1622. (doi: 10.1023/A:1026559728808)

Andreone, F., Mattioli, F., Jesu R. and Randrianirina, J. E. 2001. Two new chameleons of the genus Calumma from north-east Madagascar, with observations on hemipenial morphology in the Calumma furcifer group (Reptilia, Squamata, Chamaeleonidae). Herpetological Journal 11: 53-68.

Andreone, F., Cadle, J. E., Cox, N., Glaw, F., Nussbaum, R., Raxworthy, C., Stuart, S., Vallan, D. and Vences, M. 2005a. Species review of amphibian extinction risks in Madagascar: Conclusions from the Global Amphibian Assessment. Conservation Biology 19, 6: 17901802. (doi: 10.1111/j.1523-1739.2005.00249.x)

Andreone, F., Mercurio, V., Mattioli, F. and Razafindrabe, T. J. 2005b. Good news for three critically endangered and traded frogs from Madagascar. Froglog 72: 2-3.

Andriamampianina, J. 1976. Madagascar. In: Proceedings of International Conference on the Conservation of Wetlands and Waterfowl, Heiligenhafen, Federal Republic of Germany, 2-6 December 1974, M. Smart (ed.), pp 125-126. Slimbridge, IWRB.

Ausilio, E. \& Raveloanrinoro, G. 1998. Les lémuriens de la région de Bemaraha: Forêts de Tsimembo, de l'Antsingy et de la région de Tsiandro. Lemur News 3: 4-7

Benstead, J. P., Stiassny, M. L. J., Loiselle, P. N., Riseng, K. J. and Raminosoa, N. 2000. River conservation in Madagascar. In: Global Perspectives on River Conservation: Science, Policy and Practice. P. J. Boon, B. R. Davies and G. E. Petts (eds.), pp 205-231. John Wiley \& Sons, Chichester, U. K. 
Benstead, J. P., de Rham, P. H., Gattolliat, J.-L., Gibon, F.-M., Loiselle, P. V., Sartori, M., Sparks, J. S. and Stiassny, M. L. J. 2003. Conserving Madagascar's freshwater biodiversity. Bioscience 53, 11: 1101-1111.

Bibby, C., Martin J. and Stuart, M. 1998. Expedition Field Techniques - Bird Surveys. BirdLife International, Cambridge, U.K.

BirdLife International 2004. Threatened Birds of the World 2004. CD-ROM. Birdlife International, Cambridge, U. K.

BirdLife International 2008. Rare Birds Yearbook 2008: The World's 189 most Threatened Birds. MagDig Media Limited, Shropshire, England.

Bora, P., Dolch, R., Jenkins, R., Jovanovic, O., Rabemananjara, F. C. E., Randrianirina, J., Rafanomezantsoa, J., Raharivololoniana, L., Ramilijaona, O., Raminosoa, N., Randrianavelona, R., Raselimanana, A., Razafimahatratra, B., Razafindrabe, T. and Vences, M. 2008. Geographical distribution of the three species of Malagasy poison frogs of high conservation priority: Mantella aurantiaca, $M$. crocea and M. milotympanum. Herpetology Notes 1: 39-48.

Brown, M. 2007. The wealth of trees and the pressures of population. Madagascar Conservation \& Development 2: 3.

Butchart, S. H. M., Stattersfield, A. J. and Brooks, T. M. 2006. Going or gone: Defining 'Possibly Extinct' species to give a truer picture of recent extinctions. Bulletin of the British Ornithologists' Club 126: 7-24.

Cabeza, M. and Moilanen, A. 2001. Design of reserve networks and the persistence of biodiversity. Trends in Ecology and Evolution 16, 5: 242-248. (doi: 10.1016/S0169-5347(01)02125-5)

Carleton, M. D. and Schmidt, D. F. 1990. Systematic studies of Madagascar's endemic rodents (Muroidae, Nesomyinae): An annotated gazetteer of collecting localities of known forms. American Museum novitates 2,987: 1-36.

Carpenter, A. I. and Robson, O. 2005. A review of endemic chameleon genus Brookesia from Madagascar, and the rationale for its listing on CITES Appendix II. Oryx 39, 4: 375-380. (doi: 10.1017/S0030605305001201)

Chape, S., Harrison, J. Spalding, M. and Lysenko, I. 2005. Measuring the extent and effectiveness of protected areas as an indicator for meeting global biodiversity targets. Philosophical Transactions of the Royal Society 360, 1454: 443-455. (doi: 10.1098/rstb.2004.1592)

Collar, N. J, Crosby, M. J. and Statterfield, A. J. 1994. Birds to watch 2: The world list of threatened birds. Birdlife International, Cambridge, U. K.

D'Cruze, N., Sabel, J., Green, K., Dawson, J., Robinson, J., Starkie, G. Vences, M. and Glaw, F. 2007. The first comprehensive survey of amphibians and reptiles at Montagne des Français, Madagascar. Herpetological Conservation and Biology 2, 2: 87-99.

D'Cruze, N., Köhler, J., Franzen, M. and Glaw F. 2008. A conservation assessment of the amphibians and reptiles of the Forêt d'Ambre Special Reserve, north Madagascar. Madagascar Conservation and Development 3, 1: 44-54.

Donque, G. 1975. Contribution Géographique à I'Étude du Climat de Madagascar. Nouvelle Imprimerie des Arts Graphiques, Antananarivo.

Duplantier, J.-M. and Duchemin, J.-B. 2003. Introduced small mammals and their ectoparasites: A description of their colonization and its consequences. In: The Natural History of Madagascar. S. M. Goodman and J. P. Benstead (eds.), pp 1191-1194. The University of Chicago Press, Chicago.

Emanueli, L. and Jesu, R.. 1995. The herpetofauna of the world heritage site 'Tsingy de Bemaraha' (western Madagascar). In: Scientia Herpetologica. G. A. Llorente, A. Montori, X. Santos, and M. A. Carretero (eds.), pp 341-348. Societas Europeae Herpetologica, Barcelona, spain

Evans, M. I., Duckworth, J. W., Hawkins, A. F. A., Safford, R. J., Sheldon, B. C and Wilkinson, R. J. 1992. Key bird species of Marojejy strict nature reserve, Madagascar. Bird Conservation International 2: 201-220.

Favreau, J. M., Drew, C. A., Hess, G. R., Rubino, M. J., Koch, F. H. and Eschelbach, K. A. 2006. Recommendations for assessing the effectiveness of surrogate species approaches. Biodiversity and Conservation 15, 12: 3949-3969. (doi: 10.1007/s10531-005-2631-1)

Fisher, B. L. and Robertson, H. G. 2002. Comparison and origin of forest and grassland ant assemblages in the high plateau of Madagascar (Hymenoptera: Formicidae). Biotropica 34, 1: 155-167.

Ganzhorn, J. U. 1988. Food partitioning among Malagasy primates. Oecologia 75, 3: 436-450. (doi: 10.1007/BF00376949)
Ganzhorn, J. U., Lowry II, P. P. Schatz, G. E. and Sommer, S. 2001. The biodiversity of Madagascar: one the world's hottest hotspots on its way out. Oryx 35, 4: 346-348. (doi: 10.1111/j.1365-3008.2001.00201.pp.x)

Ganzhorn, J. U., Goodman, S. M., Nash, S. and Thalmann, U. 2006. Lemur Biogeography. In: Primate Biogeography, S. Lehman and J. G. Fleagle (eds.), pp 229-254. Springer, New York.

Garcia, G. and Goodman, S. M. 2003. Hunting of protected animals in the Parc National d'Ankarafantsika, north-western Madagascar. Oryx 37, 1 : 115-118. (doi: 10.1017/S0030605303000206)

Glaw, F. and Vences, M. 2007. A field guide to the amphibians and reptiles of Madagascar. Third edition. Vences and Glaw Verlag, Köln.

Goodman, S. M., Soarimalala, V. and Rakotondravony, D. 2001. The rediscovery of Brachytarsomys villosa F. Petter, 1962 (Rodentia, Nesomyinae), in the northern highlands of Madagascar. Mammalia 65, 1: 83-86.

Goodman, S. M., Ganzhorn, J. U. and Rakotondravony, D. 2003. Introduction to the mammals. In: The Natural History of Madagascar. S. M. Goodman and J. P. Benstead (eds.), pp 1159-1187. The University of Chicago Press, Chicago.

Hawkins, A. F A. and Goodman, S. M. 2003. Introduction to the birds. In: The Natural History of Madagascar, S. M. Goodman and J. P. Benstead (eds.), pp 1019-1044. The University of Chicago Press, Chicago.

IUCN. 2008. The IUCN Red List of Threatened Species. $<$ www.iucnredlist.org $>$.

Kati, V., Devillers, P., Dufrêne, M., Legakis, A., Vokou, D. and Lebrun, P. 2004. Hotspots, complementarity or representativeness? Designing optimal small-scale reserves for biodiversity conservation. Biological Conservation 120, 4: 471-480. (doi: doi:10.1016/j.biocon.2004.03.020)

Kirby, K. J. 1996. Conservation of habitats. In: Conservation Biology, I. F. Spellerberg (ed.), pp 141-153. Longman Press, London.

Koenig, P. \& Zavasoa, A. 2006. Totale disparition du Propithèque de Coquerel (Propithecus verreauxi coquereli) du nord de la Réserve Spéciale Bora (Province de Mahajanga). Lemur News 11: 38.

Kremen, C., Razafimahatratra, V., Guillery, R. P., Rakotomalala, J., Weiss, A and Ratsisompatrarivo, J.-S. 1999. Designing the Masoala National Park in Madagascar based on biological and socioeconomic data. Conservation Biology 13, 5: 1055-1068.

Kuchling, G. and Garcia, G. 2003. Pelomedusidae, freshwater turtles. In: The Natural History of Madagascar. S. M. Goodman and J. P. Benstead (eds.), pp 956-960. The University of Chicago Press, Chicago.

Landres, P. B., Verner, J. and Thomas, J. W. 1988. Ecological uses of vertebrate indicator species: A critique. Conservation Biology 2, 4: 316-328.

Langrand, O. 1990. Guide to the Birds of Madagascar. Yale University Press, New Haven Connecticut.

Lhota, S., J nek, T. Bartos, L. and Kub na, A. A. 2008. Specialized use of two fingers in free-ranging aye-ayes (Daubentonia madagascariensis). American Journal of Primatology 70: 786-795. (doi: 10.1002/ajp.20548)

Loiselle, P. V. and de Rham, P. 2003a. Paretroplus, Damba. In: The Natural History of Madagascar. S. M. Goodman and J. P. Benstead (eds.), pp 877-878. The University of Chicago Press, Chicago.

Loiselle, P. V. and de Rham, P. 2003b. Aplocheidiae: Pachypanchax, Malagasy Killfish. In: The Natural History of Madagascar. S. M. Goodman and J. P. Benstead (eds.), pp 870-871. The University of Chicago Press, Chicago.

Mackinnon, J. and Phillipps, K. 1993. A Field Guide to the Birds of Borneo, Sumatra, Java and Bali. Oxford University Press, Oxford.

Margules, C. R., Pressey, R. L. and Williams, P. H. 2002. Representing biodiversity: Data and procedures for identifying priority areas for conservation. Journal of Bioscience 27, 4: 309-326

McNeely, J. A., Miller, K. R., Reid, W. V., Mittermeier, R. A., and Werner, T. B. 1990. Conserving the World's Biological Diversity. World Bank, Washington, D. C., USA.

Messerli, P. 2000. Use of sensitivity analysis to evaluate key factors for improving slash-and-burn cultivation systems on the eastern escarpment of Madagascar. Mountain Research and Development 20, 1 : $32-41$.

Mittermeier, R. A., Hawkins, F., Rajaobelina, S. and Langrand, O. 2005. Wilderness conservation in a biodiversity hotspot. International Journal of Wilderness 11,3: 42-46. 
Mittermeier, R. A., Konstant, W. R., Hawkins, F., Lois Jr., E. E., Langrand, O., Ratsimbazafy, J., Rasoloarison, R., Ganzhorn, J., U., Rajaobelina, S., Tattersall, I. and Meyers, D. M. 2006. Lemurs of Madagascar. Second Edition. Conservation International, Washington, D. C.

Mori, A., Ikeuchi, I. \& Hasegawa, M. 2006. Herpetofauna of Ampijoroa, Ankarafantsika Strict Nature Reserve, a dry forest in northwestern Madagascar. Herpetological Natural History 10, 1: 31-60.

Myers, N., Mittermeier, R. A., Mittermeier, C. G., da Fonseca, G. A. B. and Kent, J. 2000. Biodiversity hotspots for conservation priorities. Nature 403: 853-858. (doi: 10.1038/35002501)

Ng, H. H. and Sparks, J. S. 2003a. The ariid catfishes (Teleostei: Siluriformes: Aridae) of Madagascar, with the description of two new species. Occasional papers of the Museum of Zoology, University of Michigan.

Ng, H. H. and Sparks, J. S. 2003b. Ariidae: Arius. In: The Natural History of Madagascar. S. M. Goodman and J. P. Benstead (eds.), pp 864-865. The University of Chicago Press, Chicago.

Nicoll, M. 2003. Forests outside protected areas. In: The Natural History of Madagascar. S. M. Goodman and J. P. Benstead (eds.), pp 1432-1437. The University of Chicago Press, Chicago.

Oldfield, T. E. E., Smith, R. J., Harrop, S. R. and Leader-Williams, N. 2004. A gap analysis of terrestrial protected areas in England and its implications for conservation policy. Biological Conservation 120, 3: 303-309. (doi: 10.1016/j.biocon.2004.03.003)

Olivieri, G., Craul, M. \& Radespiel, U. 2005. Inventaires des lémuriens dans 15 fragments de forêt de la province de Mahajanga. Lemur News 10: 11-16

Patel, E. R., Marshall, J. J. and Parathian, H. 2005. Silky sifaka (Propithecus candidus) conservation education in northeastern Madagascar. Laboratory Primate Newsletter 44, 3: 8-11.

Perennou, C. 1991. African waterfowl census: Counting waterbirds. The International Waterfowl and Wetland Research Bureau, Slimbridge.

Pressey, R. L. 1996. Protected areas: Where should they be and why should they be there? In: Conservation Biology. I. F. Spellerberg, (ed.), pp 171185. Longman Press, London.

Primack, R. B. 2002. Essentials of Conservation Biology. Third Edition. Sinauer Associates, Inc. U. S. A.

Rabarisoa, R., Watson, R. T., Thorstrom, R. and Berkelman, J. 1997. Status of the Madagascar Fish Eagle Haliaeetus vociferoides in 1995. Ostrich $68,1: 8-12$

Rabearivony, J., Fanameha, E., Mampiandra, J. and Thorstrom, R. 2008. Taboos and social contracts: Tools for ecosystem management - lessons from the Manambolomaty Lakes RAMSAR site, western Madagascar. Madagascar Conservation \& Development 3,1: 7-16.

Rabemananjara, F., Bora, P., Cadle, J. E., Andreone, F., Rajeriarison, E., Talata, P., Glaw, F., Vences, M. and Vieites, D. R. 2005. New records, distribution and conservation of Mantella bernhardi, an endangered frog species from south-eastern Madagascar. Oryx 39, 3: 339-342. (doi: 10.1017/S0030605305000736)

Rabenandrasana, M., Zefania, S., Long, P., Sam, T. S., Virginie, M. C., Randrianarisoa, M., Safford, R. and Székely, T. 2009. Distribution, habitat and status of 'Endagered' Sakalava Rail of Madagascar. Bird Conservation International 19: 23-32. (doi : doi:10.1017/ S0959270908008058)

Rakotomalala, D. 2008. La création des aires protégées dans le sud et sud ouest de Madagascar: Approche et méthodologie. Malagasy Nature 1: 168-181.

Rakotomalala, D. \& Raselimanana, A. P. 2003. Les amphibiens et les reptiles des massifs de Marojejy, d'Anjanaharibe-Sud et du couloir forestier de Betaolana. In. S. M. Goodman et L. Wilmé (eds.) Nouveaux résultats d'inventaires biologiques faisant référence à l'altitude dans la région des massifs montagneux de Marojejy et d'Anjanaharibe-Sud. pp 147202. Recherches pour le développement, Série Sciences Biologiques 19.

Ramanamanjato, J.-B., Mcintyre, P. B. and Nussbaum, R. A. 2002. Reptile, amphibian, and lemur diversity of the Malahelo Forest, a biogeographical transition zone in southeastern Madagascar. Biodiversity and Conservation 11, 10: 1791-1807. (doi: 10.1023/A:1020325415489)

Randrianambinina, B., Rasoloharijaona, S. , Rakotosamimanana, B. \& Zimmermann, E. 2003. Inventaires des communautés lémuriennes dans la Réserve Spéciale de Bora au nord-ouest et la forêt domaniale de Mahilaka-Maromandia au nord de Madagascar. Lemur News 8: 15-18.
Randrianambinina, B. and Rasoloharijaona, S. 2006. Inventaires des lémuriens nocturnes dans la forêt pluviale de Maromizaha (est de Madagascar). Lemur News 11: 9-12.

Rasamoelina, A. D. 2000. Contribution à l'Étude de la Faune Ichtyologique du Complexe des Trois Lacs : Befotaka, Soamalipo et Ankerika dans la Région d'Antsalova. D.E.A. Ecologie-Environnement. Université d'Antananarivo.

Raselimanana, A. P. 2008. Aspect de la conservation des forêts sèches malgaches. Malagasy Nature 1: 162-167.

Raselimanana, A. P. and Vences, M. 2003. Introduced reptiles and amphibians. In: The Natural History of Madagascar. S. M. Goodman and J. P. Benstead (eds.), pp 949-951. The University of Chicago Press, Chicago.

Raxworthy, C. J. 1988. Reptiles, rainforest and conservation in Madagascar. Biological Conservation 43, 3: 181-211. (doi:10.1016/00063207(88)90113-9)

Raxworthy, C. J. 2003a. Introduction to the reptiles. In: The Natural History of Madagascar. S. M. Goodman and J. P. Benstead (eds.), pp 934-949. The University of Chicago Press, Chicago.

Raxworthy, C. J. 2003b. Boidae, Boas. In: The Natural History of Madagascar. S. M. Goodman and J. P. Benstead (eds.), pp 993-997. The University of Chicago Press, Chicago.

Raxworthy, C. J and Nussbaum, R. A. 1995. Systematics, speciation and biogeography of the dwarf chameleons (Brookesia: Reptilia, Squamata, Chamaeleontidae) of northern Madagascar. Journal of Zoology, London 235, 4: 525-558. (doi: 10.1111/j.1469-7998.1995.tb01767.x)

Raxworthy, C. J. and Nussbaum, R. A. 2000. Extinction and extinction vulnerability of amphibians and reptiles in Madagascar. Amphibian and Reptile Conservation 2, 1: 15-23.

Raxworthy, C. J. and Nussbaum, R. A. 2006. Six new species of occipitallobed Calumma chameleons (Squamata: Chamaeleonidae) from montane regions of Madagascar, with a new description and revision of Calumma brevicorne. Copeia 2006, 4: 711-734.

Raxworthy, C. J., Pearson, R. G., Rabibisoa, N., Rakotondrazafy, A. M., Ramanamanjato, J.-B., Raselimanana, A. P., Wu, S., Nussbaum, R. A. and Stone, D. A. 2008. Extinction vulnerability of tropical montane endemism from warming and upslope displacement: a preliminary appraisal for the highest massif in Madagascar. Global Change Biology 14, 8: 1703-1720.

Razafimanjato, G., Sam., T. S. and Thorstrom, R. 2007. Waterbirds monitoring in the Antsalova Region, western Madagascar. Waterbirds 30, 3: 441-447.

Razanantsoa, Z. U. A. 2000. Contribution à l'étude de la population de Propithèque de Decken Propithecus verreauxi deckeni (Peters, 1870) dans la forêt de Tsimembo aux alentours du complexe des trois lacs et impact des activités humaines sur cette population. Mémoire de D.E.A. Écologie-Environnement, Département de Biologie Animale, Faculté des Sciences, Université d'Antananarivo.

Reinthal, P. N. and Stiassny, M. L. J. 1991. The freshwater fishes of Madagascar: A study of an endangered fauna with recommendations for a conservation strategy. Conservation Biology 5, 2: 231-242.

Rene de Roland, L.-A., Rabearivony, J., Randriamanga, I. and Thorstrom, R. 2004. Nesting biology and diet of the Madagascar Harrier (Circus macrosceles) in Ambohitantely Special Reserve, Madagascar. Journal of Raptor Research 38, 3: 256-262.

Rene de Roland, L.-A., Sam, T. S., Rakotondratsima, M. P. H. and Thorstrom, R. 2007. Rediscovery of the Madagascar Pochard Aythya innotata in northern Madagascar. Bulletin of the African Bird Club 14, 2: 171-174.

Rene de Roland, L.-A., Thorstrom, R., Razafimanjato, G., Rakotondratsima, M. P. H., Andriamalala, T. R. A. and Sam, T. S. 2009. Surveys, distribution and current status of the Madagascar Harrier Circus macrosceles in Madagascar. Bird Conservation International 19, 4: 309-322. (doi: 10.1017/S095927090900817X)

Rodrigues, A. S. L., Andelman, S. J., Bakarr, M. I., Boitani, L., Brooks, T. M., Cowling, R. M., Fishpool, L. D. C., da Fonseca, G. A. B., Gaston, K. J., Hoffmann, M., Long, J. S., Marquet, P. A., Pilgrim, J. D., Pressey, R. L., Schipper, J., Sechrest, W., Stuart, S. N., Underhill, L. G., Waller, R. W., Watts, M. E. J. and Yan, X. 2004. Effectiveness of the global protected area network in representing species diversity. Nature 428: 640-643. (doi: 10.1038/nature02422) 
Salvan, J. 1970. Remarques sur l'évolution de l'avifaune malgache depuis 1945. Alauda 38: 191-203.

Schimmenti, G. and Jesu, R. 1997. Some significant reptile discoveries from the Antsingy Forest ("Tsingy de Bemaraha" Massif, western Madagascar). In Proceedings of the eighth ordinary general meeting of the Societas Herpetologica Europaea. W. Böhme, W. Bischoff, and T. Ziegler (eds), pp 317-329. Bonn (SEH).

Scott, D. and Lubbock, J. 1974. Preliminary observations on waterfowl of western Madagascar. Wildfowl 25: 117-121.

Scott, J. M., Ramsey, F. L. and Kepler, C. B. 1981. Distance estimation as a variable in estimating bird numbers. In: Estimating Numbers of Terrestrial Birds, C. J. Ralph and J. M. Scott, (eds), pp 334-340. Studies in Avian Biology 6. Cooper Ornithological Society.

Seddon, N., Tobias, J., Yount, J. W., Ramanampamonjy, J. R., Butchart, S. and Randrianizahana, H. 2000. Conservation issues and priorities in the Mikea Forest of south-west Madagascar. Oryx 34,4: 287-304.

Seddon, N. and Tobias, J. A. 2007. Population size and habitat associations of the Long-tailed Ground-roller Uratelornis chimaera. Bird Conservation International 17: 1-12. (doi: 10.1017/S095927090600058X)

Soarimalala, V. and Goodman, S. M. 2003. Diversité biologique des micromammifères non volants (Lipotyphla et Rodontia) dans le complexe Marojejy - Anjanaharibe-Sud. In: Nouveaux résultats d'inventaires biologiques faisant référence à l'altitude dans la région des massifs montagneux de Marojejy et d'Anjanaharibe-Sud, S. M. Goodman et L. Wilmé (eds.), pp 231-278. Recherches pour le Développement, Série Sciences Biologiques 19.

Sparks, J. S. 2003. Ptychochromis. In: The Natural History of Madagascar, S M. Goodman and J. P. Benstead (eds.), pp 873-874. The University of Chicago Press, Chicago.

Sparks, J. S. and Stiassny, M. L. J. 2003. Introduction to the freshwater fishes. In: The Natural History of Madagascar, S.M. Goodman and J. P. Benstead (eds.), pp 849-863. The University of Chicago Press, Chicago.

Sparks, J. S. and Stiassny, M. L. J. 2008. Les poissons d'eau douce. In: Paysages Naturels et Biodiversité de Madagascar, S. M. Goodman (ed.), pp. 283-309. Publications Scientifiques Muséum National d'Histoire Naturelle (MNHN), Paris

Sparks, J. S. and Stiassny, M. L. J. 2010. A new species of Ptychochromis from northeastern Madagascar (Teleostei: Cichlidae), with an updated phylogeny and revised diagnosis for the genus. Zootaxa 2341: 33-51.

Stephenson, P. J. 1993. The small mammal fauna of Réserve Spéciale d'Analamazaotra, Madagascar: The effects of human disturbance on endemic species diversity. Biodiversity and Conservation 2: 603-615.

Sterling, E. J. 1994. Taxonomy and distribution of Daubentonia: A historical perspective. Folia Primatologica 62: 8-13. (doi: 10.1159/000156758)

Stiassny, M. L. J. and Raminosoa, N. 1994. The fishes of the inland waters of Madagascar. In: Biological Diversity in African Fresh and Brackish Water Fishes. Geographical Overviews, Symposium PARADI, G. G. Teugels, J.-F. Geugan, and J.-J. Albaret (eds.), pp 275: 133-149. Annales Muséum Royal de l'Afrique Centrale, Sciences Zoologiques.

Stuart, S. N, Chanson, J. S., Cox, N. A., Young, B. E., Rodrigues, A. S. L., Fischman, D. L. and Walter, R. W. 2004. Status and trends of amphibian declines and extinctions worldwide. Science 306: 1783-1786. (doi: 10.1126/science.1103538)

The Peregrine Fund 2008a. Inventaire Biologique et Étude Socio-économique dans la Région de Mandrozo, District de Maintirano. Rapport Final. The Peregrine Fund, Antananarivo.

The Peregrine Fund 2008b. Inventaire Biologique et Étude Socioéconomique dans la Région de Bemanevika, District de Bealanana. Rapport Final. The Peregrine Fund, Antananarivo.

Thompson, P. M. and Evans, M. I. 1992. The threatened birds of Ambatovaky Special Reserve, Madagascar. Bird Conservation International 2: 221 237.

Thorstrom, R. and Rabarisoa, R. G. M. 1995. An observation of Madagascar Teal Anas bernieri in northwestern Madagascar. Wildfowl 47: 212-215.

Thorstrom, R. and Rene de Roland, L.-A. 2001. First nest descriptions, nesting biology and food habits for Bernier's Vanga, Oriolia bernieri, in Madagascar. Ostrich 72,3-4: 165-168.
Thorstrom, R. and Rene de Roland, L.-A. 2003a. Strigiformes: Tyto soumagnei, Madagascar Red Owl, Vorondolomena. In: The Natural History of Madagascar. S. M. Goodman and J. P. Benstead (eds.), pp 1110-1113. The University of Chicago Press, Chicago.

Thorstrom, R. and Rene de Roland, L.-A. 2003b. Eutriorchis astur, Madagascar Serpent-eagle. In: The Natural History of Madagascar. S. M. Goodman and J. P. Benstead (eds.), pp 1088-1091. The University of Chicago Press, Chicago.

Thorstrom, R., Rene de Roland, L.-A and Watson, R. T. 2003. Falconiformes and Strigiformes: Ecology and status of raptors. In: The Natural History of Madagascar. S. M. Goodman and J. P. Benstead (eds.), pp 1080-1085. The University of Chicago Press, Chicago.

Tobias, J. A. and Seddon, N. 2002. Estimating population size in the subdesert mesite (Monias benschi): New methods and implications for conservation. Biological Conservation 108, 2: 199-212. (doi: 10.1016/ S0006-3207(02)00106-4)

Vallan, D. 2002. Effects of anthropogenic environmental changes on amphibian diversity in the rain forests of eastern Madagascar. Journal of Tropical Ecology 18: 725-742. (doi: 10.1017/S026646740200247X)

Vallan, D. 2003. Consequences of rain forest fragmentation for herpetofauna: A case study for Ambohitantely. In: The Natural History of Madagascar. S. M. Goodman and J. P. Benstead, (eds), pp 899-907. The University of Chicago Press, Chicago.

Watson, R. T. and Rabarisoa, R. 2000. Sakalava fishermen and Madagascar Fish Eagles: Enhancing traditional rules to control resource abuse that threatens a key breeding area for an endangered eagle. Ostrich 71, 1-2: 2-10.

Watson, R. T., Thomsett, S., O'Daniel, D. and Lewis, R. 1996. Breeding, growth, development and management of the Madagascar Fish Eagle (Haliaeetus vociferoides). Journal of Raptor Research 30, 1: 21-27.

Watson, R. T., Rene de Roland, L.-A., Rabearivony, J. and Thorstrom, R. 2007 Community-based wetland conservation protects endangered species in Madagascar: Lessons from science and conservation. Banwa 4: 81-95.

Young, H. G., Lewis, R. E. and Razafindrajao, F. 2003. Anseriformes: Anatidae, Wildfowl. In: The Natural History of Madagascar. S. M. Goodman, and J. P. Benstead (eds), pp 1077-1080. The University of Chicago Press, chicago.

Zimmermann, H. 1996. Der Schutz des tropischen Regenwaldes und ein kleines Fröschchen in Ost-Madagaskar. Stapfia 47: 189-218.

Zimmermann, H. and Hetz, S. 1992. Vorläufige Bestandsaufnahme und Kartierung des gefährdeten Goldfröschchens Mantella aurantiaca, im tropischen Regenwald Ost-Madagaskars. Herpetofauna 14: 33-34. 
APPENDIX 1. VOUCHER SPECIMENS FROM BEMANEVIKA.

Reptiles: Brookesia therezieni (UADBA 42578, 42579 and 42580), Calumma hafahafa (UADBA 42582, 42583 and 42584), Calumma crypticum (UADBA 42585 and 42586), Calumma boettgerie (UADBA 42600), Uroplatus ebenaui (UADBA 42587), Zonosaurus madagascariensis (UADBA 42588), Trachylepis gravenhorstii (UADBA 42589, 42590), Lygodactylus guibei (UADBA 42592), Madascincus mouroundavae (UADBA 42591, 42593, 42594 and 42595), Madascinus intermedius (UADBA 42596, 42597, 42598 and 42599).

Amphibians: Heterixalus andrakata (UADBA 42601 and 42602), Aglyptodactylus madagascariensis (UADBA 42613, 42614, 42615, 42616 and 42617), Boophis axelmeyeri (UADBA 42646), Boophis cf. brachychir (UADBA 42653 and 42654), Boophis cf. madagascariensis (UADBA 42643 and 42644), Boophis marojezensis (UADBA 42655, 42656, 42657 and 42658), Boophis vittatus (UADBA 42659 and 42660), Boophis cf. vittatus (UADBA 42662), Blommersia blommersae (UADBA 42619 and 42620), Blommersia sp. (UADBA 42621 and 42622), Gephyromantis ambohitra (UADBA 42633, 42634, 42635, 42636, 42637, 42638, 42639 and 42640), Gephyromantis cf. ambohitra (UADBA 42632), Mantella pulchra (UADBA 42618), Mantidactylus femoralis (UADBA 42626), Mantidactylus guttulatus (UADBA 42628 and 42629), Mantidactylus mocquardi (UADBA 42627), Mantidactylus opiparis (UADBA 42630), Spinomantis peraccae (UADBA 42642), Plethodontohyla sp. (UADBA 42605, 42606, 42607, 42608, 42609 and 62645), Rhombophryne alluaudi (UADBA 42603 and 42604), Scaphiophryne boribory (UADBA 42610 and 42611), and Ptychadena mascareniensis (UADBA 42612).

\section{SUPPLEMENTARY MATERIAL.}

AVAILABLE ONLINE ONLY:

List of species recorded at the three SAPM sites, endemism and IUCN status ( $1=$ species present but not recorded during this study; $2=$ species present and found by local community; *=recorded species) (IUCN categories: DD=data deficient, $\mathrm{LC}=$ least concern, $\mathrm{VU}=$ vulnerable, $\mathrm{NT}=$ near threatened, $\mathrm{EN}=$ endangered, $\mathrm{CR}=$ critically endangered). 